\title{
Grazer-controlled recruitment of the introduced Sargassum muticum (Phaeophyceae, Fucales) in northern Europe
}

\author{
Kjersti Sjøtun $^{1, *}$, Sarah F. Eggereide ${ }^{1,2}$, Tore Høisæter ${ }^{1}$ \\ ${ }^{1}$ University of Bergen, Department of Biology, PO Box 7800, 5020 Bergen, Norway \\ ${ }^{2}$ Present address: Directorate of Fisheries, PO Box 2009, Nordnes, 5817 Bergen, Norway
}

\begin{abstract}
Sargassum muticum (Yendo) Fensholt was introduced to European coasts during the 1970s. We studied survival and growth of seeded S. muticum germlings in field experiments on the southwestern coast of Norway, close to its present northernmost limit of distribution in Europe. A cage experiment was conducted twice (using different starting densities of germlings) at 2 localities during the summer and autumn of 2002, each experiment lasting 1 mo. Germling survival was significantly higher within grazer-excluding cages than on unprotected substrate. Germlings within cage controls (cages accessible to mesograzers) experienced intermediate mortality, which was nevertheless closer to that of unprotected than to cage-protected germlings. At a third locality, survival of unprotected germlings was recorded from September 2000 to February 2001, and only 0.6\% of the germlings had survived by February. When relating proportion of mortality to initial density of germlings, we found no tendency of positive density-dependent mortality; on the contrary, on the substrate where grazers had access to the germlings, there was a tendency for high mortality when initial density was low and lower mortality when initial density was high. This suggests a 'swamping' effect of high germling densities on grazers. The growth of germlings during autumn and winter was very low compared with earlier reported measurements from Spain, and we suggest that relatively slow growth rates may make the germlings vulnerable to grazing impact. The results indicate that herbivorous grazing on early post-settlement stage germlings may be a limiting factor for the spread of $S$. muticum in southwestern Norway.
\end{abstract}

KEY WORDS: Sargassum muticum • Grazing · Introduced alga · Cage experiment · Germlings • Mesoherbivores

Resale or republication not permitted without written consent of the publisher

\section{INTRODUCTION}

Introduced marine species may have unpredictable effects on indigenous communities, and are therefore receiving increasing attention (Eno et al. 1997, Hopkins 2001, Boudouresque \& Verlaque 2002, Levin et al. 2002). In the North Sea, at least 80 new species have arrived owing to anthropogenic activity, and more than 50 of these have arrived during the last 100 yr (Reise et al. 1999). Macroalgae constitute a big group of introduced marine species in the northeast Atlantic, and 20 of the 80 new species in the North Sea identified by 1999 were macroalgae (Reise et al. 1999). Macroalgae occupy a narrow zone along the coasts, from the intertidal zone to about $30 \mathrm{~m}$ depth. Consequently, only a few successfully introduced benthic algae occupying this zone may be sufficient to cause extensive changes to the indigenous communities.

There are several examples of community effects caused by invasive benthic algae. The circumtropical green alga Caulerpa taxifolia has spread rapidly and colonized large areas of the Mediterranean Sea, and may outcompete the seagrass Posidonia oceanica locally (de Villèle \& Verlaque 1995, but see also Jaubert et al. 2003). In the northwest Atlantic, Codium fragile subsp. tomentosoides replaces kelp vegetation 
in the Gulf of Maine by colonizing gaps in the kelp beds and thus preventing kelp recolonization (Levin et al. 2002). Another example of a successful invasive alga is Sargassum muticum, which was first recorded in Europe in southern England in 1973 (Farnham et al. 1973). It rapidly spread southward and northward from the English Channel, and drifting plants were recorded for the first time on the south coast of Norway in 1984, and then attached plants for the first time in 1988 (Rueness 1989). In Europe, S. muticum is currently distributed from northern Portugal to the southwest coast of Norway $\left(61^{\circ} \mathrm{N}\right)$ (Steen 1992, 2004). It is normally found in the lower intertidal zone, the shallow sublittoral zone and in rock pools (Fletcher \& Fletcher 1975, Fernández et al. 1990, Karlsson \& Loo 1999). In Washington, USA, Norton (1977) reported it to be rare below 3 to $4 \mathrm{~m}$ below middle low water.

After establishment of Sargassum muticum in an area of European waters, a relatively rapid increase in local abundance has often been observed (e.g. Farnham et al. 1981, Critchley et al. 1987, Karlsson \& Loo 1999, Stæhr et al. 2000), and in Limfjorden (Denmark), a concurrent decline in abundance of other macroalgae has been reported (Stæhr et al. 2000). However, a more gradual increase in abundance with time is also reported in some cases, e.g. in France (Cosson 1999) and Norway (Rueness \& Steen 1997). On the southwest coast of Norway, S. muticum was first observed in 1991 (Steen 1992). At present it is still spreading locally in this area, and shows a slow increase in distribution and abundance (K. Sjøtun pers. obs.). Thus, S. muticum appears to be less invasive in its northernmost area of distribution in Europe than in many other places, but the reason for this is not known.

Field measurements of large plants suggest that Sargassum muticum growth is slower in Norway than in southern England, especially during winter (Steen 1992). Growing relatively slowly may reduce the competitive abilities of $S$. muticum. Because slow-growing germlings may be vulnerable to grazers (Vadas et al. 1992), a reduced growth capacity can also result in reduced recruitment. Several studies suggest that Sargassum spp. are susceptible to grazing by sea urchins (De Wreede 1983), herbivorous fish (McCook 1996), amphipods and gastropods (Norton \& Benson 1983). Grazing is probably the most important factor in reducing survival of juvenile fucoid algae (Vadas et al. 1992, Chapman 1995). Experiments in Canada and USA demonstrated heavy grazing on germlings of some Fucus spp. by Littorina spp. and gammarid amphipods, while adult algae were not seriously affected (Lubchenco 1983, Parker \& Chapman 1994).

Thomsen et al. (2006) did not find any correlation between grazers (Littorina littorea and Psammechinus miliaris) and percentage cover of Sargassum muticum in Limfjorden (Denmark). As far as we know, with the exception of Thomsen et al. (2006) few studies have been made on grazing on adult or juvenile stages of $S$. muticum in Europe. Germlings and reproduction processes of $S$. muticum in Europe have been mainly studied in the laboratory (e.g. Hales \& Fletcher 1989, 1990, Steen 2003a,b), or in field conditions in southern Europe (e.g. Andrew \& Viejo 1998a,b, Fernández 1999). Field studies have shown a short range of dispersal of germlings from the parent plant (Deysher \& Norton 1982, Andrew \& Viejo 1998a), limitation of recruitment by lack of free space (Andrew \& Viejo 1998a), and a strong positive density-dependent mortality of juveniles (Andrew \& Viejo 1998b). In Australia, Kendrick (1994) observed positive density-dependent mortality of Sargassum spp. germlings with settlement densities of $<10 \mathrm{~cm}^{-2}$, and a negative influence on survival of recruits older than 6 mo by canopy vegetation. However, high density-independent mortality was also observed (Kendrick 1994).

In this study, we present results on the survival and growth of early post-settlement (EPS) stages (sensu Vadas et al. 1992) of Sargassum muticum on the southwest coast of Norway, and test the hypothesis that grazing on the germling stage has an impact on recruitment of $S$. muticum. Lubchenco (1983) showed that Fucus vesiculosus longer than 3 to $5 \mathrm{~cm}$ escaped Littorina spp. grazing, and growth rate of fucoid germlings may consequently be important for survival of germlings when exposed to mesograzers. In order to assess the influence of grazing on germling mortality, we conducted a field experiment using cages.

\section{MATERIALS AND METHODS}

Study sites. Survival and development of EPS stages of Sargassum muticum germlings, seeded in the laboratory and transferred to the sea shortly after seeding, were recorded at 3 localities on the southwest coast of Norway, in the vicinity of Bergen. At Site A, situated at Nautnes $\left(60^{\circ} 37^{\prime} \mathrm{N}, 4^{\circ} 48^{\prime} \mathrm{E}\right)$, germlings were monitored between 28 September 2000 and 26 February 2001. At Sites B and C, situated at Espegrend $\left(60^{\circ} 16^{\prime} \mathrm{N}, 5^{\circ} 13^{\prime} \mathrm{E}\right), 2$ cage experiments were conducted, Expt 1 from 6 August to 6 September and Expt 2 from 17 September to 18 October 2002.

Site A was situated in an outer archipelago, in a narrow sound with relatively strong tidal currents. Saccharina latissima (formerly Laminaria saccharina, see Lane et al. 2006) dominated the vegetation, and small patches of Sargassum muticum were observed in shallow parts of the sound. Sites B and C were situated in a sheltered area with small islands in a fjord system. No $S$. muticum was observed naturally growing at these 
sites. Site B was situated about 20 to $25 \mathrm{~m}$ from a small island, and the bottom was dominated by sand and gravel, partly covered with different brown algae intermingled with bare spots. Site $\mathrm{C}$ was situated in a small sandy bay with little algal vegetation, and with rather steep, rocky walls at both sides.

Measurements of survival and development of germlings. Seeding of Sargassum muticum germlings was achieved by maintaining $S$. muticum branches (originating from several plants) in aerated containers until germlings were liberated from the receptacle surfaces, as described by Fletcher (1980).

For the experiment at Site A, the germlings were collected and kept in suspension and allowed to settle with different densities on 9 sandpaper-rubbed Plexiglas plates $(6 \times 6 \mathrm{~cm}$ and divided into marked squares of $1 \mathrm{~cm}^{2}$ ). Different settling densities were obtained by diluting the germling suspension. Earlier studies showed that 2 to $3 \mathrm{~d}$ old $S$. muticum germlings quickly attach and hold firm to substratum by the sticky terminal regions of the rhizoid initial cells (Fletcher 1980). If such young germlings are torn loose, as in the seeding process of this study, reattachment also takes place, albeit more slowly (Deysher \& Norton 1982). The germlings were kept at $10^{\circ} \mathrm{C}$ and exposed to a photon fluence rate of around $50 \mu \mathrm{mol} \mathrm{m} \mathrm{m}^{-2} \mathrm{~s}^{-1}$ during seeding. After $9 \mathrm{~d}$, germlings were counted within areas of 2 or $4 \mathrm{~cm}^{2}$ of each plate (depending on germling density) by use of a stereo microscope with additional dimmed light. The germlings were constantly submerged in sea water during the counting process. The edges of the plates were avoided. The seeded germling density varied between 75 and 414 germlings $\mathrm{cm}^{-2}$ on the plates. Before transportation to Site A, and during each check, a number of haphazardly selected germlings were removed from some of the plates outside the marked squares allocated to the counting of germlings, and the lengths of these were measured ( $n=12$ to 40 ). The length from the base to the most distant part of the apical tip was recorded.

Transport of the plates to Site A took place $9 \mathrm{~d}$ after seeding. The plates were placed in plastic beakers filled with sea water and transported in a cooling bag. One additional plate seeded with germlings was included during transportation and returned to the culture room, in order to check if transportation could have resulted in any additional mortality of the germlings. The seeded plexiglas plates were placed along both sides of the sound within a stretch of about 150 m, avoiding steep areas and patches with Sargassum muticum. Each plate was fastened with a bolt on a small footing $(15 \times 15 \times 7 \mathrm{~cm})$ made of cement (nontoxic type), and placed in the algal vegetation on rocky bottom, 15 to $45 \mathrm{~cm}$ below lowest astronomical tide (LAT). An empty plate was attached to 5 of the foot- ings. Three $S$. muticum germlings were recorded on 1 of these during the experiment, suggesting negligible natural recruitment of $S$. muticum on the experimentally seeded plates. Survival and length of germlings were recorded on 26 October and 24 November 2000, and at the termination of the experiment on 26 February 2001. During each recording, the germlings were counted in the same area on the plate as in the laboratory by using a stereo microscope with dimmed light. The plates were examined at the field station of the Institute of Marine Research at Nautnes, situated close to Site A. The plates with germlings were kept constantly submerged during the recordings, and were transferred back to the same local spot after each check.

For the experiments at Sites B and C, germlings were seeded in the laboratory directly onto 15 granite plates per site, each plate measuring $10 \times 10 \mathrm{~cm}$. An effort was made to distribute the germlings as evenly as possible across the plates during settlement. Germlings were kept in running sea water and low light (not measured) in the laboratory for $3 \mathrm{~d}$ (Expt 1) or $5 \mathrm{~d}$ (Expt 2) after seeding. During this time, germlings were counted on selected parts of the granite plates in the same way as for the experiment at Site A. The initial density of germlings was lower by a factor of 10 to 15 in the first experiment than in the second (average numbers per granite plate: 48 to $93 \mathrm{~cm}^{-2}$ in the first experiment, and 845 to $1144 \mathrm{~cm}^{-2}$ in the second). There was no significant difference in density among the sites or experimental treatments (see below) within each experiment (2-way ANOVA, p > 0.05 for all combinations).

The germlings were kept submerged in water under transportation to Sites B and C, and 1 granite plate was taken back to check for possible additional mortality owing to transportation. At Sites B and C, the granite plates were placed at 70 to $90 \mathrm{~cm}$ below LAT. The granite plates were randomly distributed among 3 experimental treatments, with 5 plates in each: (1) 'cage', in which the footing carrying the granite plate was totally enclosed within a plankton net (mesh size of $800 \mu \mathrm{m})$, (2) 'cage control', in which the footing carrying the granite plate was enclosed within a plankton net with holes cut open at all 4 sides, allowing smaller animals to enter but maintaining the shadowing effect provided by the plankton net, and (3) 'unprotected', a footing carrying a granite plate without a plankton net covering. At each site, the granite plates of the 3 different experimental treatments were placed haphazardly but interspersed on the sea floor, at 20 to $50 \mathrm{~cm}$ distance from each other.

Sites B and C were checked regularly at 3 to $5 \mathrm{~d}$ intervals. Detritus and algal growth on the plankton nets were gently removed, and animals seen on or around the granite plates were recorded. During 
Expt 1, the results from 2 plates from Site C were omitted because the footings had been turned over, presumably by an anchor. On terminating each experiment, the granite plates were brought back to the laboratory and the germlings counted within the same squares as before the treatments. Germlings that had lost their apical tip were not counted, because earlier observations revealed that loss of the meristoderm zone results in mortality. In addition, other features on the plates were noted e.g. invertebrates or other algae. Indications of grazing marks on germlings were documented by photographs.

At Sites B and C, the length of a number of haphazardly selected germlings was measured before and after each experiment, in the same way as at Site A. At the start of each experiment, between 50 and 100 germlings were removed from 2 to 4 plates and measured; when finishing each experiment, between 24 and 128 germlings were removed from 1 to 5 granite plates per treatment and measured.

Monitoring of temperature and light. The water temperature was measured at $50 \mathrm{~cm}$ depth nearly every day in the vicinity of Sites B and C during both experiments. Sea water temperature data were not available from Site A, but temperature measurements carried out at irregular intervals from 5 October 2000 to 20 February 2001 at $3 \mathrm{~m}$ depth at a scallop cultivation plant in the vicinity of Site A were included. Tidal currents and good circulation of sea water on the outer part of the coast result in relatively homogeneous sea water temperatures in this area.

A data logger (LI-1000) connected to 2 underwater quantum sensors measuring photon fluence rate was installed at Site C during the first experiment. The sensors were placed on the bottom among the granite plates: one sensor was uncovered while the other was covered with plankton net. The logger was placed on land nearby.

Statistical treatment. Data on survival/mortality of germlings were calculated and analysed as proportions. The data analysis was performed using Statistica 6.0 and JMP IN 5.1. The ratio of highest to lowest variance was used as a rough test for whether variances were homogeneous enough to accept the results of ANOVA F-tests (Green 1979). Owing to heterogeneous variances, the survival proportions could not be tested for the complete set of results from Exp 1. Therefore, the experimental treatments were tested separately for each site-experiment combination in four 1-way ANOVAs. Tukey's Honestly Significant Difference (HSD) was used as a post-hoc test. Germling survival was correlated with initial density of seeded germlings, using Pearson's correlation coefficient. Germling lengths at the end of the experiments were correlated with initial and final density of germlings, and with amount of germlings removed during each experiment. Proportion data were arcsine transformed before analyses; otherwise, $\log (x+1)$ transformation was used. Results of statistical testing were considered to be significant if $\mathrm{p}<0.05$.

\section{RESULTS}

\section{Temperature and light}

At the start of October 2000, water temperature was $13.1^{\circ} \mathrm{C}$ in the vicinity of Site $\mathrm{A}$, and decreased to a minimum of $5^{\circ} \mathrm{C}$ on 20 February 2001. During Expt 1 (August to September) at Sites B and C, the temperature was between $21^{\circ} \mathrm{C}$ at the start and $18.5^{\circ} \mathrm{C}$ at the end of the experiment. During Expt 2 (September to October), the temperature continuously declined from 16.5 to $11^{\circ} \mathrm{C}$.

The maximum photon fluence rate varied between 600 and $800 \mu \mathrm{mol} \mathrm{m}{ }^{-2} \mathrm{~s}^{-1}$ during 11 of the $27 \mathrm{~d}$ in which light was measured at Site $\mathrm{C}$ during the first experiment. For the remainder of the time, the maximum photon fluence rate normally varied between 100 and $500 \mu \mathrm{mol} \mathrm{m} \mathrm{m}^{-2} \mathrm{~s}^{-1}$. The sensor covered by the plankton net showed much lower values. On most days, the maximum light photon fluence rate varied between 50 and $200 \mu \mathrm{mol} \mathrm{m} \mathrm{m}^{-2} \mathrm{~s}^{-1}$; however, on $4 \mathrm{~d}$, values reached between 200 and $450 \mu \mathrm{mol} \mathrm{m} \mathrm{m}^{-2} \mathrm{~s}^{-1}$.

\section{Germling survival}

Germling proportional survival from the 2 cage experiments at Sites B and C is shown in Fig. 1. While there were considerable differences within each experimental group, both between the 2 sites and between experiments, the main tendency was clear: the germlings enclosed in cages had the highest mean survival (68 to $87 \%$ in the first experiment and 62 to $85 \%$ in the second), and unprotected germlings had the lowest survival (5 to $11 \%$ in Expt 1 and 13 to $61 \%$ Expt 2). In addition, the survival of germlings in the cage control treatment was generally more similar to that of germlings in the unprotected treatment than to those in the cage treatment. At Site B, a significantly higher proportion of germlings survived in the cage treatment than in the other 2 treatments during both experiments, while there was no significant difference between the unprotected treatment and the cage control treatment in either experiment (Fig. 1). Also, at Site $\mathrm{C}$, the germling proportional survival in the cage treatment was significantly higher than that in the unprotected treatment during both experiments (Fig. 1). While there was no difference between germling pro- 


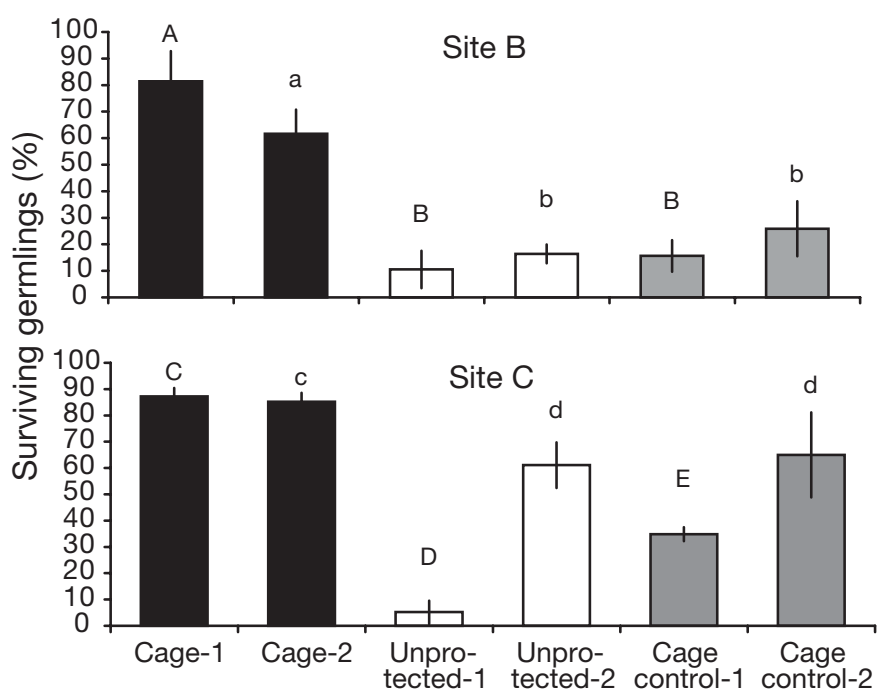

Fig. 1. Sargassum muticum. Proportional survival (mean with $95 \%$ CI) of EPS germlings at Sites B and C in experimental treatments 'cage' (black bars), 'unprotected' (white bars) and 'cage control' (grey bars); numbers refer to experiment number; $\mathrm{n}=4$ to 5. Significant differences (Tukey's HSD, $\mathrm{p}<$ 0.05 ) among experimental treatments of Expts $1 \& 2$ (analysed separately) indicated by letters: $A \neq B, a \neq b, C \neq D \& E, C \neq d$. Similar lettering of histograms indicate no significant difference

portional survival in the unprotected and the cage control treatment at Site C in Expt 2, germling survival in the cage control treatment was intermediate and significantly different from survival in both the cage and the unprotected treatment in Expt 1 (Fig. 1).

The initial seeding density of germlings was many times higher in Expt 2 than in Expt 1. Also, germling absolute mortality (no. of germlings removed $\mathrm{cm}^{-2}$ ) was many times higher in Expt 2 compared with Expt 1, irrespective of experimental treatment. In addition, in Expt 2, a clear difference was found between Sites B and $C$, with higher survival proportions at Site $C$ than at Site B in all experimental treatments (Fig. 1). In the unprotected and cage control treatment up to 1100 germlings $\mathrm{cm}^{-2}$ were removed at Site $\mathrm{B}$, whereas a maximum of around $500 \mathrm{~cm}^{-2}$ were removed at Site C.

In order to test a possible relationship between settling density and subsequent mortality of germlings in the different treatments, the proportion of removed germlings in each category was plotted against the initial density of germlings (Fig. 2). The results from Site A were included in the unprotected treatment. In spite of a large spread around the regression line, a significant negative correlation between mortality and initial density was found in the unprotected $(\mathrm{r}=0.4, \mathrm{p}=$ $0.032)$ and in the cage control treatment $(\mathrm{r}=0.47, \mathrm{p}=$ $0.044)$. On most of the unprotected experimental plates with relatively low seeding density, the mortality rate of EPS germlings after 1 mo was 80 to $100 \%$ (Fig. 2). No significant correlation was recorded in the cage treatment ( $\mathrm{r}=0.14, \mathrm{p}=0.6$ ) (Fig. 2). In the unprotected treatment, the results showed a clear difference between Sites B and C when initial germling density

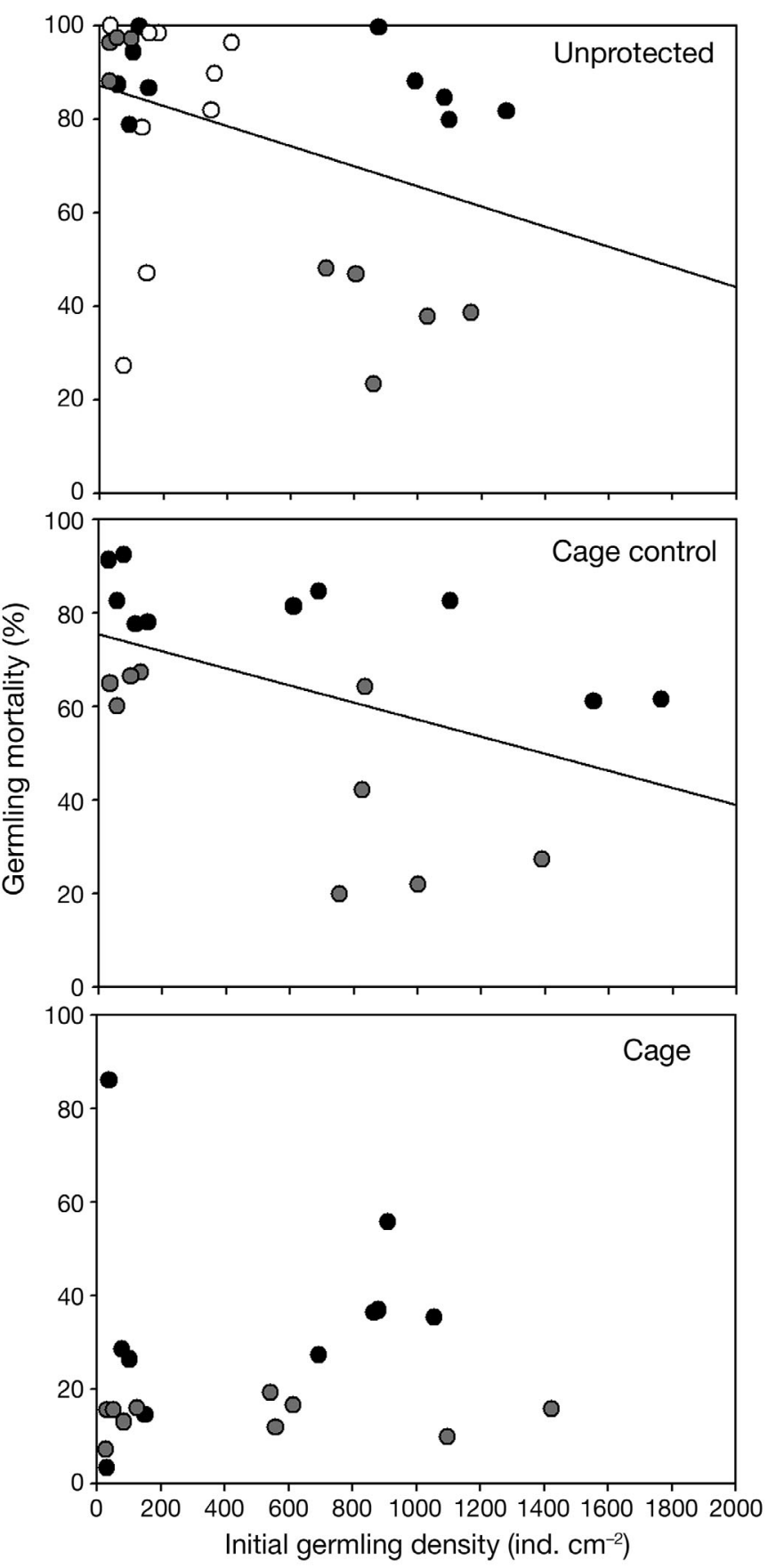

Fig. 2. Sargassum muticum. Proportional mortality of EPS germlings after $1 \mathrm{mo}$ in relation to initial density (ind. $\mathrm{cm}^{-2}$ ); all data from unprotected (upper plot), cage control (middle plot) and cage (lower plot) treatments at Sites A (O), B (•) and C (O) shown. Regression line for data from unprotected $\left(r^{2}=\right.$ $0.16)$ and for cage control treatment $\left(\mathrm{r}^{2}=0.22\right)$ shown 


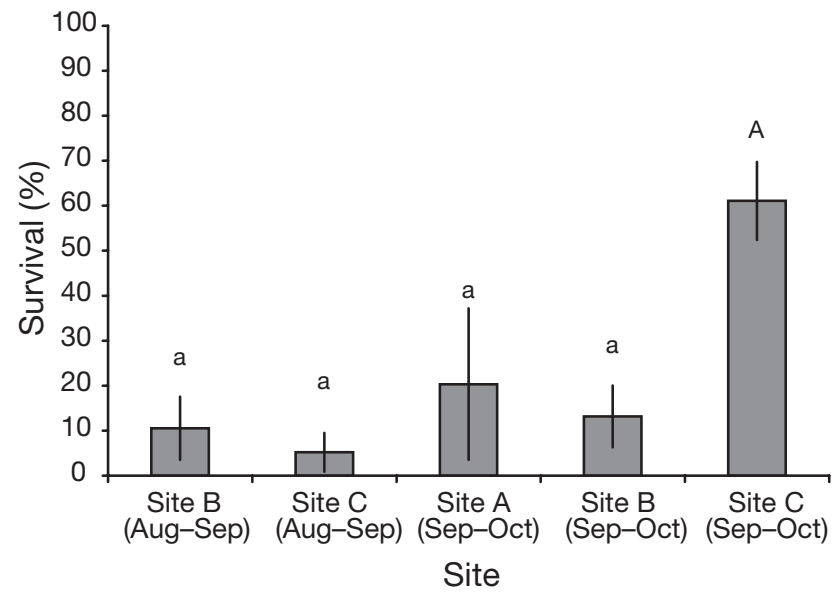

Fig. 3. Sargassum muticum. Proportional survival after 1 mo (mean with $95 \% \mathrm{CI}$ ) of EPS germlings at Site A during September-October 2000, and at Sites B and C during August-September and September-October 2002; $\mathrm{n}=5$ to 9 . Significant differences (Tukey's HSD, p < 0.05) among samplings indicated by letters: $\mathrm{A} \neq \mathrm{a}$

was high (Expt 2), with generally lower mortality on the 5 plates from Site $C$ than on those from Site B (Fig. 2, uppermost rates plot).

Survival of unprotected EPS germlings after $1 \mathrm{mo}$ between August and October at all sites was compared (Fig. 3). At Site A, a mean of $20 \%$ had survived for 1 mo in October 2000. Only $0.6 \%$ remained in February 2001 (data not shown). Survival after 1 mo was between 5 and $61 \%$ at Sites B and C, with a significantly higher mean proportion of survival at Site C from September to October 2002 (Expt 2) than in the other groups (1-way ANOVA, p $<0.001$; Tukey's HSD, p < $0.05)$. No significant differences between other groups were found.

\section{In situ observations of potential grazers and algal growth}

At Sites B and C, Littorina littorea was frequently observed on, or in the vicinity of, the unprotected granite plates. At all 3 stations, marks on germlings were observed that indicated grazing, e.g. removal of the apical tip (Fig. 4A). However, at Sites B and C, these marks were most abundant on the germlings in the cage treatment, and least abundant on the germlings in the unprotected treatment. On the granite plates in the cage treatment, a high number of amphipod tubes were observed, many of which had been constructed partly or entirely of germlings. Around these it was common to see a cleared area of germlings (Fig. 4B). Amphipod tubes among the seeded germlings in combination with high numbers of germlings with grazing marks were also observed at Site A. Some large sea urchins (Echinus esculentus) were observed at Site B, but never on the granite plates.

During Expt 1, small green algae were observed growing on the unprotected and cage control treatment plates at Sites B and C. The green algae were $<1 \mathrm{~cm}$ long, filamentous and occurred in patches, and were most abundant on the unprotected granite plates at Site C.

\section{Length development of germlings}

At Site $\mathrm{A}$, the $9 \mathrm{~d}$ old germlings measured about $0.2 \mathrm{~mm}$ at the start of the experiment in September 2000. After $1 \mathrm{mo}$ in the sea, in October, they measured
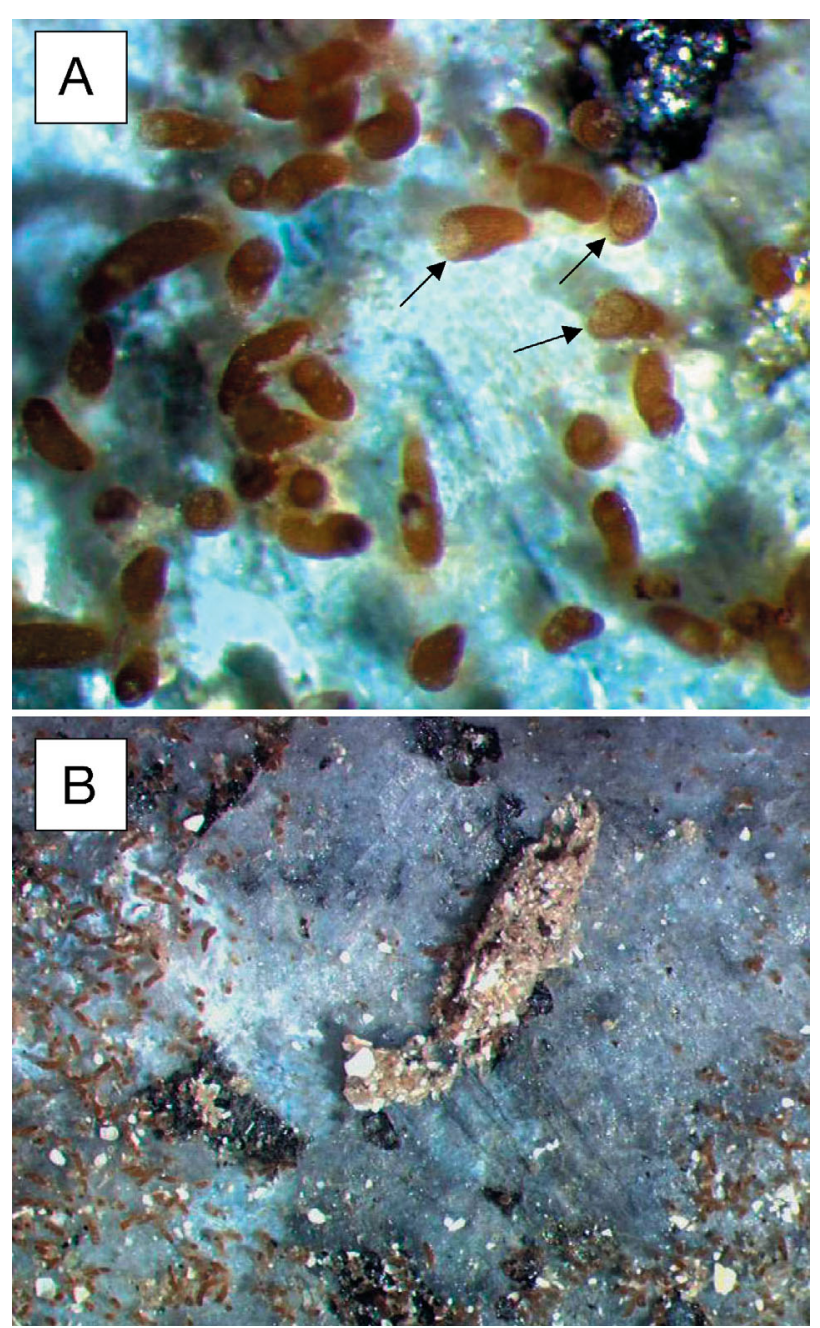

Fig. 4. Sargassum muticum. Germlings (1 mo old, mean length $\sim 0.6 \mathrm{~mm}$ ) from cage treatment, Expt 2, Site C. (A) Germlings with grazing marks shown by arrows. (B) Area clear of germlings around an amphipod tube 


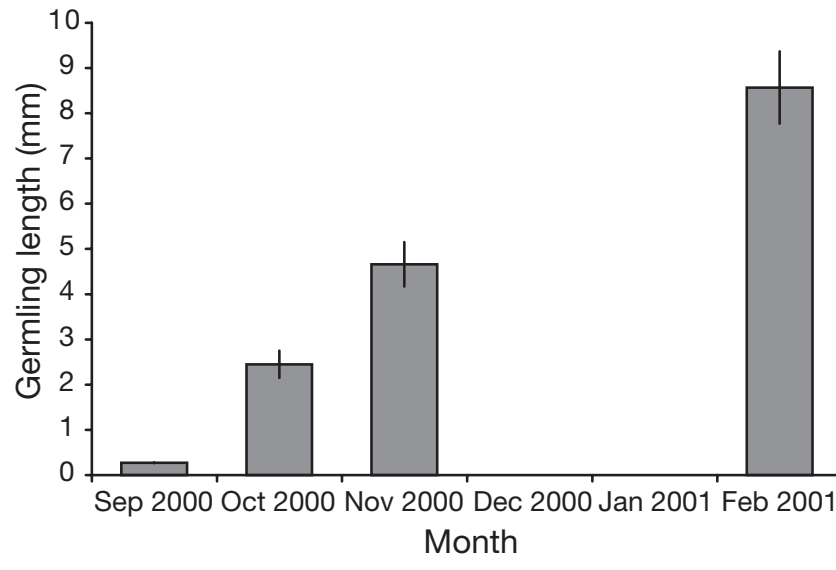

Fig. 5. Sargassum muticum. Length development ( $\mathrm{mm}$; mean with $95 \%$ CI) from 28 September 2000 to 26 February 2001 at Site A ( $\mathrm{n}=12$ to 40$)$

between 2 and $3 \mathrm{~mm}$, and after 5 mo, in February 2001, the mean length of the surviving germlings was about $9 \mathrm{~mm}$ (Fig. 5).

At Sites B and C, the germlings were about $0.18 \mathrm{~mm}$ mean length at the start of Expt 1 and $0.15 \mathrm{~mm}$ at the start of Expt 2. After $1 \mathrm{mo}$, the germlings were generally shortest in the cage treatment, with mean lengths less than $1.0 \mathrm{~mm}$ on most of the individual granite plates in both experiments (Figs. 6 \& 7). The longest germlings were found on some granite plates in the cage control treatment in Expt 1, with average lengths of around $2.5 \mathrm{~mm}$ (Fig. 6).

Since environmental conditions changed during the study, the results from the 2 experiments were analysed separately. No significant relationship between initial settling density and resultant mean length of germlings was found in any of the categories. However, when correlating the final mean lengths of germlings with the number of germlings removed from the granite plates (Figs. 6A \& 7A), a significant correlation was found in both Expt 1 $(\mathrm{r}=0.64, \mathrm{p}<0.01)$ and Expt $2(\mathrm{r}=0.62, \mathrm{p}<0.001)$. However, when correlating the final germling lengths with number of germlings removed in each treatment, the correlation was significant only for the unprotected treatment in Expt 2 (regression line in Fig. $7 A_{i} r=0.56, p<0.01$ ). Also, there was a significant negative relationship between germling length and final germling density in the treatments exposed to grazers in Expt $2(\mathrm{r}=0.56, \mathrm{p}<0.01)$, but not in Expt 1 (Figs. 6B \& 7B). The growth of germlings in the cage treatment was generally low and did not show a response to removal of germlings, or to final density, in any of the experiments (Figs. 6B \& 7B), suggesting that the cages had an additional negative effect on growth.

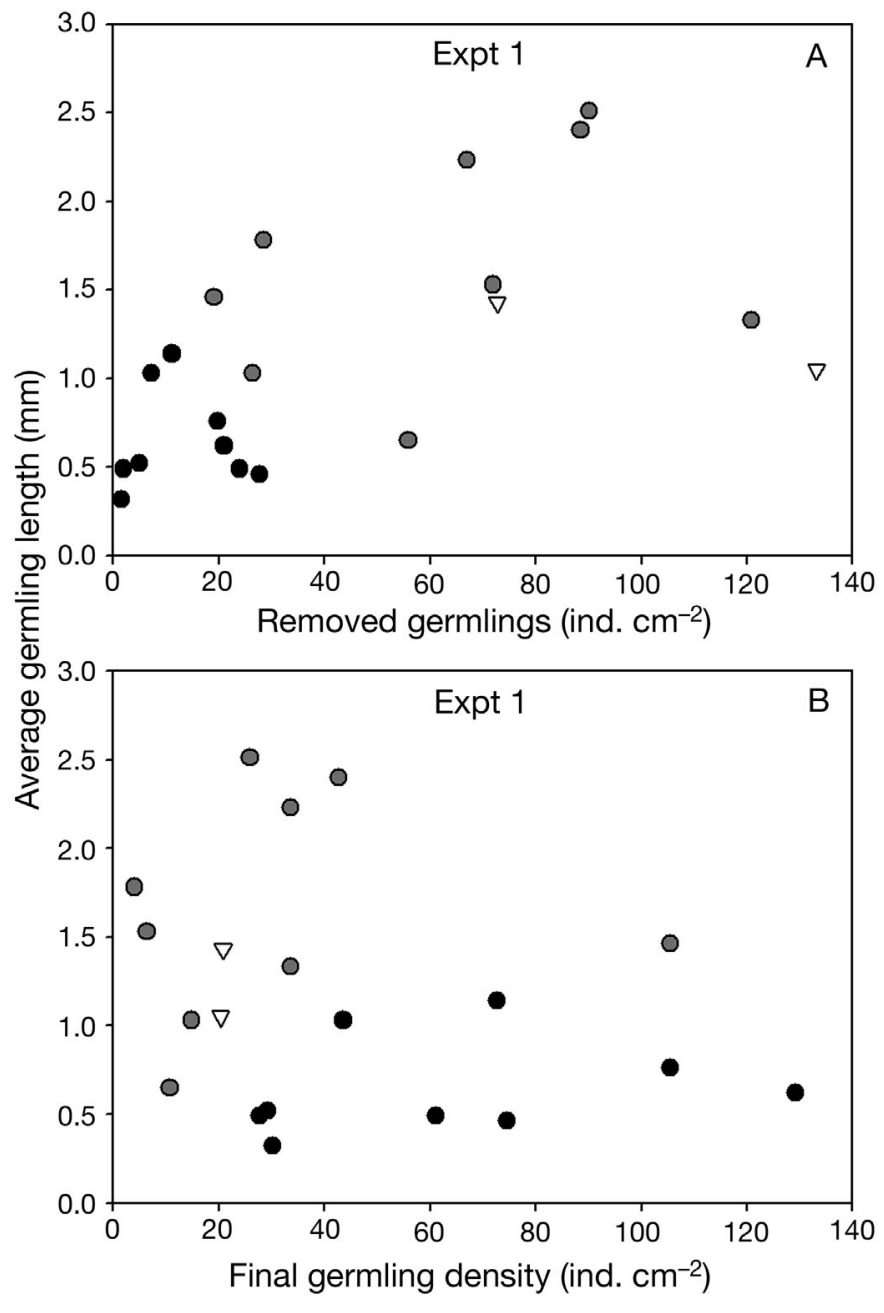

Fig. 6. Sargassum muticum. Germling lengths ( $\mathrm{mm}$; mean per granite stone) after 1 mo as a function of (A) germlings removed (ind. $\mathrm{cm}^{-2}$ ) and (B) final density of germlings (ind. $\mathrm{cm}^{-2}$ ) in Expt $1 .(\bullet)$ : Cage treatment; $(0)$ : cage control; $(\nabla)$ : unprotected treatment

\section{DISCUSSION}

\section{Survival of Sargassum muticum EPS germlings}

These field experiments simulated a situation with dense settlement of Sargassum muticum germlings in patches of free substratum among the benthic vegetation, in the shallow subtidal zone where $S$. muticum grows most abundantly in Europe. S. muticum produces numerous germlings with a relatively short dispersal range (Deysher \& Norton 1982), which can result in crowded settlement close to parental plants. Deysher \& Norton (1982) recorded a settlement density of 100 juvenile $S$. muticum $\mathrm{cm}^{-2}$ within $1 \mathrm{~m}$ from the parental plants, decreasing to 1 plantlet $\mathrm{m}^{-2}$ at $5 \mathrm{~m}$ distance of the parental plants. In the present study, the 


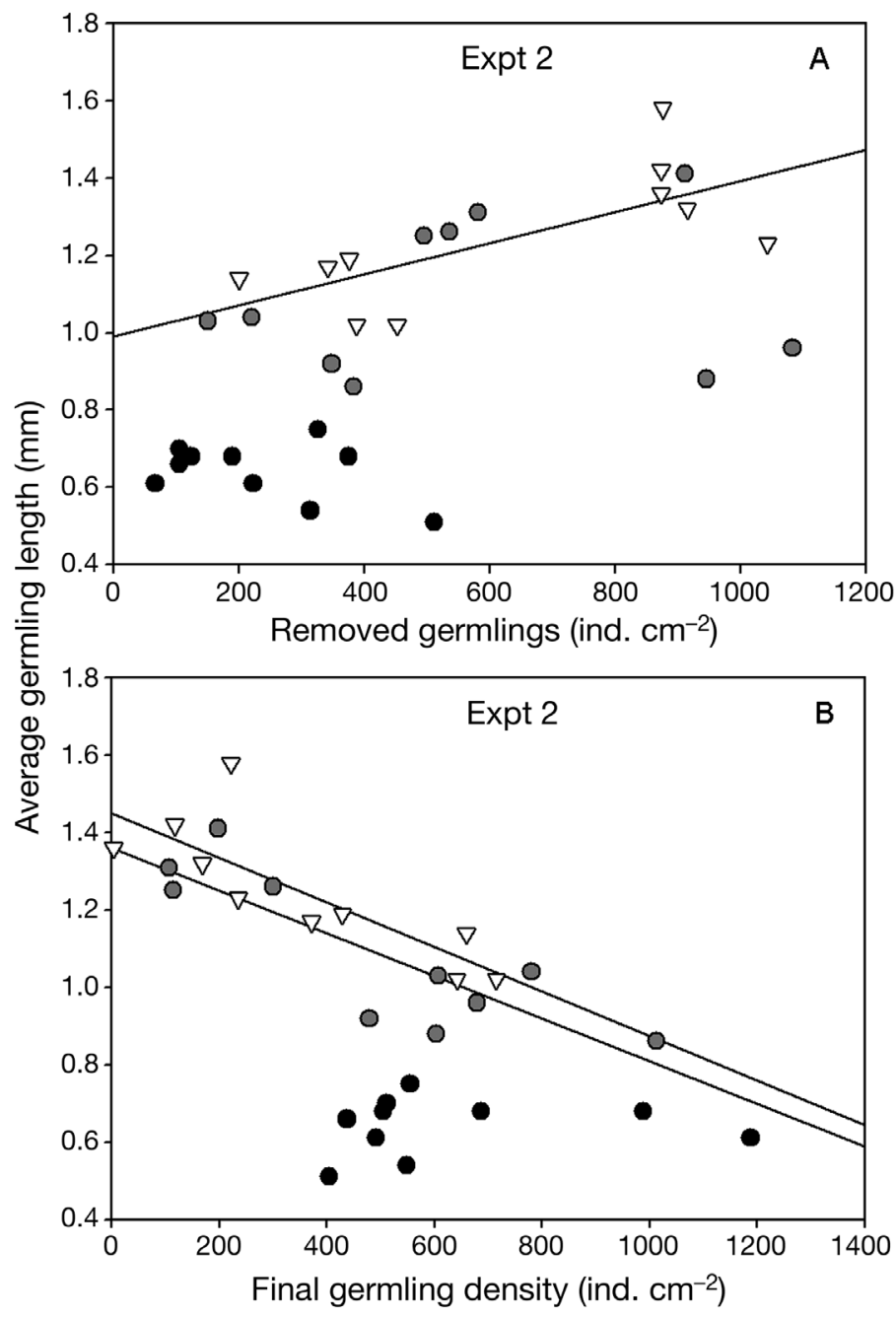

Fig. 7. Sargassum muticum. Germling lengths ( $\mathrm{mm}$; mean per granite stone) after $1 \mathrm{mo}$ as a function of (A) germlings removed (ind $\mathrm{cm}^{-2}$ ) and (B) final density of germlings (ind. $\mathrm{cm}^{-2}$ ) in Experiment 2. (๑): Cage treatment; (O): cage control; $(\nabla)$ : unprotected treatment. Lines shown for regressions significant at $\mathrm{p}<0.05$ for (A) unprotected treatment and

(B) unprotected (upper line) and cage control treatment

highest seeding densities of germlings are probably too high to reflect natural recruitment densities of $S$. muticum germlings. Nevertheless, the wide range of settlement densities made it possible to examine whether or not the proportion of surviving germlings after 1 mo could be dependent on settlement density.

Positive density-dependent mortality and selfthinning after recruitment is common in benthic algal vegetations, but seems to be most important when grazing pressure or disturbance rate is low (Santelices 1990). In a laboratory study of Sargassum muticum, a high proportion of germling mortality was recorded when high settlement density was combined with added nutrients and high temperature (Steen 2003b).
In Spain, field studies of $S$. muticum demonstrated a clear positive relationship between density and mortality, suggesting strong intraspecific competition and self-thinning (Andrew \& Viejo 1998b, Arenas \& Fernández 2000). However, there is generally little evidence of density-dependent mortality during the first phase of fucoid recruitment (Chapman 1995). In the present field study, germling mortality after 1 mo was generally highest on the plates with lowest initial density, except for those that were protected by cages. Consequently, this study showed no evidence of density-dependent mortality of unprotected $S$. muticum EPS germlings (Holm 1990). Also, the fact that initial density of the germlings did not influence length growth suggests that there was little intraspecific competition among germlings during the initial recruitment phase.

Enclosing the germlings within a fine-meshed net had a pronounced positive effect on survival in most cases. The increased survival of germlings after being enclosed in a cage is most likely due to protection from grazing. It might be argued that high germling survival within the cages could result from protection from high irradiance and photodestruction, or protection from sweeping by the surrounding benthic algal vegetation by the plankton net cover. High photon fluence rates may be harmful to EPS germlings of Sargassum muticum. Hales \& Fletcher (1989) found high mortality of germlings during the first 2 wk of cultures grown at an irradiance of $88 \mu \mathrm{mol} \mathrm{m}^{-2} \mathrm{~s}^{-1}$ or more. In the present study, the maximum irradiance per day was much higher than $88 \mu \mathrm{mol} \mathrm{m}^{-2} \mathrm{~s}^{-1}$ during the first experiment, but the light measurements suggested that the fine-meshed plankton net strongly reduced irradiance. However, recordings of high mortality of germlings in the cage control treatment in which the germlings were equally well protected from high irradiance and sweeping effects as those in the cage treatment revealed that neither of these factors could account for the highest survival of germlings within the cages.

We propose that mesograzers are the most probable candidates for causing the main part of the observed mortality of Sargassum muticum EPS germlings in the present study. The openings in the plankton net of the cage control treatment were too small to allow large sea urchins to enter and, in addition, sea urchins were never observed on the granite plates. Several gastropods, amphipods and isopods of the littoral and upper sublittoral zone are known to be browsers. Littorina littorea was observed on the unprotected granite plates at Sites B and C, and is an important grazer in the intertidal zone (Lubchenco 1983, Lotze et al. 2001). It may also be an important mesograzer in the upper sublittoral zone. We ob- 
served that $L$. littorea grazes small $S$. muticum germlings in the laboratory. In addition, we suggest that amphipods could be important grazers on the germlings. The species Ampithoe rubricata and Microprotopus maculatus were identified in samples from the granite plates. Of these, at least $A$. rubricata is known to be herbivorous (Norderhaug 2004).

Amphipods and denuded areas around amphipod tubes were observed on the granite plates of the cage treatment, in combination with marks on germlings that indicated grazing on these germlings. Consequently, the germlings enclosed by plankton net were not totally unimpacted by grazers, and this probably contributed to the variable mortality of between 10 and $40 \%$ of the germlings in this treatment. It is likely that some amphipods were transferred from the adult plants to the granite plates during the seeding process. A number of juvenile amphipods were discovered and removed from the granite plates while the germlings were counted before the experiments, but probably not all were discovered. In addition, juvenile amphipods may have penetrated the plankton nets around the caged granite plates.

During Expt 2, the initial densities of EPS germlings were much higher than in Expt 1. The absolute mortality of germlings was also much higher after 1 mo, especially at Site B. We suggest that the high densities of germlings in Expt 2 also offered more food for mesograzers, and probably attracted more grazers. However, a tendency for an increasing proportion of surviving germlings with increasing settling density in the unprotected and cage control treatments suggests that grazers were 'swamped' (sensu Vadas et al. 1992) by high germling densities.

In Expt 2, when initial germling density was high, there was a pronounced difference between germling mortality at Sites B and C, with higher survival at Site C. Site C had a sandy substratum and generally less benthic vegetation than did Site B. Mesograzers often live in association with algal vegetation (e.g. Norderhaug 2004), and a habitat with little algal vegetation may thus be favourable for survival from mesograzers. Interestingly, in Norway, Sargassum muticum is common on sandy substrata with little other algal vegetation (Steen 1992).

\section{Importance of EPS germling length development}

In a laboratory study, Sargassum muticum germlings measured around $9 \mathrm{~mm}$ after 1 mo under optimal conditions (Hales \& Fletcher 1989). In the present field study, the maximum mean length of surviving germlings was about $2 \mathrm{~mm}$ after $1 \mathrm{mo}$, suggesting far-fromoptimal conditions for growth. In addition, germlings exposed to the different treatments grew to dissimilar lengths, suggesting heterogeneous conditions for growth between the experimental treatments within each site.

The results suggest that substantial removal or thinning of germlings can result in greater growth (in terms of length) when the initial settling density is high. In Expt 2 at Sites B and C, where the initial densities of germlings were around $1000 \mathrm{~cm}^{-2}$, there was a clear negative relationship between mean germling length and germling density at the end of the experiment in those treatments where grazers had access to the germlings. This suggests that grazers may reduce intraspecific competition among $S$. muticum germlings in patches with high settlement density, and thereby provide better growth conditions for the surviving germlings.

However, the results also indicate that the ambient physical conditions influenced growth of the germlings. The germlings enclosed in cages showed no growth response to germling removal or to final density of germlings, and the overall low growth in this treatment suggests that the enclosed condition with little water circulation was unfavourable for the germlings. Laboratory studies have shown that Sargassum muticum germling growth increases with increasing temperature up to $25^{\circ} \mathrm{C}$, and becomes light saturated at $44 \mu \mathrm{mol} \mathrm{m} \mathrm{m}^{-2} \mathrm{~s}^{-1}$ (Hales \& Fletcher 1989). Thus, the ambient sea temperature was close to optimum for growth at Sites B and C during the first experiment, but well below during the second experiment and at Site A. However, the maximum irradiance at midday was normally far above light values that are known to cause reduced growth of $S$. muticum EPS germlings (Hales \& Fletcher 1989). This may have caused photoinhibition and reduced growth of germlings in the unprotected treatment, and may explain why germlings did not grow best in the unprotected treatment during the first experiment.

In a field experiment in Spain, Sargassum muticum germlings that had settled from June onwards were around $2 \mathrm{~cm}$ long in September, and had achieved a maximum mean length of about $11 \mathrm{~cm}$ at 2 sheltered sites in January the following year (Andrew \& Viejo 1998b). Our results show that the length growth rate of germlings during the first half of the year is very low in southwest Norway compared with that observed after settlement in Spain. We suggest that the timing of seasonal germling production, in combination with more adverse conditions for growth, is responsible for the relatively slow growth rate of germlings in Norway compared with further south. The timing of our experiments was related to the period of maximum germling production in Norway, which is from July to September (Steen 1992). In southern England, Fletcher \& Fletcher 
(1975) found fertile plants between May and September, with maximum fertility between June and July. This means that while the majority of $S$. muticum germlings are produced during mid-summer further south, the period of maximum fertility is shifted to late summer and early autumn in Norway. During autumn, the nutrient content of coastal Norwegian waters is low in non-eutrophicated areas, the sea temperature of shallow water rapidly sinks well below the optimum for growth for S. muticum, and day-lengths shorten. Both nutrient starvation and decreasing temperatures below $25^{\circ} \mathrm{C}$ will reduce growth in $\mathrm{S}$. muticum germlings (Steen 2003b).

A slow growth rate of germlings increases the risk of being eliminated, e.g. by grazers or disturbance. The results of the present study suggest that the majority of the germlings are removed before density-dependent mortality develops after settling, and that grazing by mesoherbivores is a main cause of mortality of Sargassum muticum EPS germlings. High mortality owing to grazing also explains why proportional survival of germlings in the unprotected and cage control treatment appears, at least to some degree, to be highest on experimental plates with the highest initial densities, because this can be explained by 'swamping'. This could mean that the higher the settling densities of the germlings at a locality, the higher the chances that some escape grazing and survive the first winter. This implies that the success of $S$. muticum at its northernmost limit of distribution in Europe may be very much dependent on high production and successful settlement of germlings around established patches of $S$. muticum. After high settlement, stochastic spatial and temporal escapes from grazing by the germlings will facilitate successful recruitment. However, if abiotic conditions for $S$. muticum germlings vary among years, with e.g. better growth conditions for germlings during some years, one may expect more escapes from grazers and higher recruitment in these years. In addition, our results suggest that moderate grazing may be beneficial for germlings under certain circumstances by reducing intraspecific competition and thereby improving the growth conditions in dense patches.

Effects of mesograzers on benthic algal communities have rarely been studied in the sublittoral, probably owing to problems with handling this group in controlled experiments. However, some studies have shown that mesograzers may have a serious impact on the structure of macroalgal vegetation (Parker \& Chapman 1994, Duffy \& Hay 2000, Lotze et al. 2001). Effects of grazing on Fucus spp. can be negative through high removal of germlings (Parker \& Chapman 1994), or positive through removal of endophytes or opportunistic and competing algae (Parker \& Chapman 1994, Worm et al. 2000).
Sargassum muticum possesses 'ephemeral' traits with large seasonal fluctuations in biomass, and in the autumn nearly all the annual production is lost from a population (Pedersen et al. 2005). The populations are probably dependent on high annual recruitment for persistence. The results of the present study suggest that mesoherbivores can possibly control abundance of $S$. muticum in Norway by removing slow-growing recruits. Effects of mesograzers on juvenile stages probably vary greatly among algal species, and also among species of grazers (Lotze et al. 2001, Van Alstyne et al. 2001). Van Alstyne et al. (2001) suggested that algae have 2 strategies for surviving the juvenile stage: (1) allocating the majority of resources to growth and less to defence in order to outgrow mesograzers, (2) allocating resources to defence and consequently growing more slowly. Compared with other fucoids, $S$. muticum germlings grow relatively fast under optimum conditions (Steen \& Rueness 2004), and therefore possibly rely on the first strategy. However, this will result in high risk of being grazed when the juveniles grow under suboptimal conditions in an environment with high grazing impact. In order to assess the effects of mesoherbivores on recruitment of $S$. muticum and its competitors in different regions, it is necessary to identify the most important mesograzers and carry out controlled experiments on how these respond to juvenile stages of these algae.

Acknowledgements. We thank B. R. Olsen for assistance with field work, L. Buhl-Mortensen for identification of amphipods, Scalpro Ltd. for use of sea temperature data and the Institute of Marine Research for use of facilities. We are grateful to 4 anonymous reviewers for comments that greatly improved the manuscript. This study was partially supported by Sunniva and Egil Baardseth's Legacy.

\section{LITERATURE CITED}

Andrew NL, Viejo RM (1998a) Ecological limits to the invasion of Sargassum muticum in northern Spain. Aquat Bot 60:251-263

Andrew NL, Viejo RM (1998b) Effects of wave exposure and intraspecific density on the growth and survivorship of Sargassum muticum (Sargassaceae: Phaeophyta). Eur J Phycol 33:251-258

Arenas F, Fernández C (2000) Size structure and dynamics in a population of Sargassum muticum (Phaeophyceae). J Phycol 36:1012-1020

Boudouresque CF, Verlaque M (2002) Biological pollution in the Mediterranean Sea: invasive versus introduced macrophytes. Mar Pollut Bull 44:32-38

Chapman ARO (1995) Functional ecology of fucoid algae: twenty-three years of progress. Phycologia 34:1-32

Cosson J (1999) Sur la disparition progressive de la Laminaria digitata sur les côtes du Calvados (France). Cryptogam Algol 20:35-42

Critchley AT, Nienhuis PH, Verschuure K (1987) Presence 
and development of populations of the introduced brown alga Sargassum muticum in the southwest Netherlands. Hydrobiologia 151/152:245-255

de Villèle X, Verlaque M (1995) Changes and degradation in a Posidonia oceanica bed invaded by the introduced tropical alga Caulerpa taxifolia in the North Western Mediterranean. Bot Mar 38:79-87

De Wreede RE (1983) Sargassum muticum (Fucales, Phaeophyta): regrowth and interaction with Rhodomela larix (Ceramiales, Rhodophyta). Phycologia 22:153-160

Deysher L, Norton TA (1982) Dispersal and colonization in Sargassum muticum (Yendo) Fensholt. J Exp Mar Biol Ecol 56:179-195

Duffy JE, Hay ME (2000) Strong impacts of grazing amphipods on the organization of a benthic community. Ecol Monogr 70:237-263

Eno NC, Clark RA, Sanderson WG (1997) Non-native marine species in British waters: a review and directory. Joint Nature Conservation Committee, Peterborough

Farnham WF, Fletcher RL, Irvine LM (1973) Attached Sargassum found in Britain. Nature 243:231-232

Farnham W, Murfin C, Critchley A, Morrell S (1981) Distribution and control of the brown alga Sargassum muticum. In: Levring $\mathrm{T}$ (ed) Proc Xth Int Seaweed Symp. Walter de Gruyter, Berlin, p 277-282

Fernández C (1999) Ecology of Sargassum muticum (Phaephyta) on the North coast of Spain: IV. Sequence of colonization on a shore. Bot Mar 42:553-562

Fernández C, Gutiérrez LM, Rico JM (1990) Ecology of Sargassum muticum on the north coast of Spain: preliminary observations. Bot Mar 33:423-428

Fletcher RL (1980) Studies of the recently introduced brown alga Sargassum muticum (Yendo) Fensholt. III. Periodicity in gamete release and 'incubation' of early germling stages. Bot Mar 23:425-432

Fletcher RL, Fletcher SM (1975) Studies on the recently introduced brown alga Sargassum muticum (Yendo) Fensholt. I. Ecology and reproduction. Bot Mar 18:149-156

Green RH (1979) Sampling design and statistical methods for environmental biologists. John Wiley, New York

Hales JM, Fletcher RL (1989) Studies on the recently introduced brown alga Sargassum muticum (Yendo) Fensholt IV. The effect of temperature, irradiance and salinity on germling growth. Bot Mar 32:167-176

Holm ER (1990) Effects of density-dependent mortality on the relationship between recruitment and larval settlement. Mar Ecol Prog Ser 60:141-146

Hopkins CCE (2001) Actual and potential effects of introduced marine organisms in Norwegian waters, including Svalbard. Research Report 2001-1, Directorate for Nature Management, Trondheim

Jaubert JM, Chrisholm JRM, Minghelli-Roman A, Marchioretti M, Morrow JH, Ripley HT (2003) Re-evaluation of the extent of Caulerpa taxifolia development in the northern Mediterranean using airborne spectrographic sensing. Mar Ecol Prog Ser 263:75-82

Karlsson J, Loo LO (1999) On the distribution and the continuous expansion of the Japanese seaweed-Sargassum muticum-in Sweden. Bot Mar 42:285-294

Kendrick GA (1994) Effects of propagule settlement density and adult canopy on survival of recruits of Sargassum spp. (Sargassaceae: Phaeophyta). Mar Ecol Prog Ser 103: 129-140

Lane CE, Mayes C, Druehl LD, Saunders GW (2006) A multigene molecular investigation of the kelp (Laminariales, Phaeophyceae) supports substantial taxonomic re-organization. J Phycol 42:493-512
Levin PS, Coyer JA, Petrik R, Good TP (2002) Communitywide effects of nonindigenous species on temperate rocky reefs. Ecology 83:3182-3193

Lotze HK, Worm B, Sommer U (2001) Strong bottom-up and top-down control of early life stages of macroalgae. Limnol Oceanogr 46:749-757

Lubchenco J (1983) Littorina and Fucus: effects of herbivores, substratum heterogeneity, and plant escapes during succession. Ecology 64:1116-1123

McCook LJ (1996) Effects of herbivores and water quality on Sargassum distribution on the central Great Barrier Reef: cross-shelf transplants. Mar Ecol Prog Ser 139:179-192

Norderhaug KM (2004) Use of red algae as hosts by kelpassociated amphipods. Mar Biol 144:225-230

Norton TA (1977) Ecological experiments with Sargassum muticum. J Mar Biol Assoc UK 57:33-43

Norton TA, Benson MR (1983) Ecological interactions between the brown seaweed Sargassum muticum and its associated fauna. Mar Biol 75:169-177

Parker T, Chapman ARO (1994) Separating the grazing effects of periwinkles and amphipods on a seaweed community dominated by Fucus distichus. Ophelia 39:75-91

Pedersen MF, Stæhr PA, Wernberg T, Thomsen MS (2005) Biomass dynamics of exotic Sargassum muticum and native Halidrys siliquosa in Limfjorden, Denmark-implications of species replacements on turnover rates. Aquat Bot 83:31-47

Reise K, Gollash S, Wolff WJ (1999) Introduced marine species of the North Sea coasts. Helgol Meeresunters 52: 219-234

Rueness J (1989) Sargassum muticum and other introduced Japanese macroalgae: biological pollution of European coasts. Mar Pollut Bull 20:173-176

Rueness J, Steen H (1997) Status for spredning av Sargassum muticum (japansk drivtang) i Norge. Presented at the annual meeting of the Association of Norwegian Oceanographers. In: The Association of Norwegian Oceanographers. Annual report: book of abstracts

Santelices B (1990) Patterns of reproduction, dispersal and recruitment in seaweeds. Oceanogr Mar Biol Annu Rev 28:177-276

Stæhr PA, Pedersen MF, Thomsen MS, Wernberg T, KrauseJensen D (2000) Invasion of Sargassum muticum in Limfjorden (Denmark) and its possible impact on the indigenous macroalgal community. Mar Ecol Prog Ser 207:79-88

Steen H (1992) Sargassum muticum i Norge: Årssyklus og utbredelse i relasjon til toleranse overfor regulerende miljøfaktorer. MS dissertation, University of Oslo

Steen H (2003a) Development and competitive interactions in fucoid germlings (Fucales, Phaeophyceae) - effects of nutrients, temperature, salinity, and settlement density. $\mathrm{PhD}$ dissertation, University of Oslo

Steen H (2003b) Intraspecific competition in Sargassum muticum (Phaeophyceae) germlings under various density, nutrient and temperature regimes. Bot Mar 46:36-43

Steen H (2004) Effects of reduced salinity on reproduction and germling development in Sargassum muticum (Phaeophyceae, Fucales). Eur J Phycol 39:293-299

Steen H, Rueness J (2004) Comparison of survival and growth in germlings of six fucoid species (Fucales, Phaeophyceae) at two different temperature and nutrient levels. Sarsia 89: 175-183

Thomsen MS, Wernberg T, Stæhr PA, Pedersen MF (2006) Spatio-temporal distribution patterns of the invasive macroalga Sargassum muticum within a Danish Sargassum-bed. Helgol Mar Res 60:50-58

Vadas RL, Johnson S, Norton TA (1992) Recruitment and 
mortality of early post-settlement stages of benthic algae. Br Phycol J 27:331-351

Van Alstyne KL, Whitman SL, Ehlig JM (2001) Differences in herbivore preferences, phlorotannin production, and nutritional quality between juvenile and adult tissues from

Editorial responsibility: Otto Kinne (Editor-in-Chief), Oldendorf/Luhe, Germany marine brown algae. Mar Biol 139:201-210

Worm H, Lotze HK, Sommer U (2000) Coastal food-web structure, carbon storage and nitrogen retention regulated by consumer pressure and nutrient loading. Limnol Oceanogr 45:339-349

Submitted: July 4, 2006; Accepted: January 19, 2007 Proofs received from author(s): July 1, 2007 